J. Clin. Chem. Clin. Biochem.

Vol. 28, 1990, pp. 533-541

(C) 1990 Walter de Gruyter \& Co.

Berlin $\cdot$ New York

\title{
Altered Erythrocyte CR1 Binding Kinetics Compensate for Decreased Binding Capacity in Rheumatoid Arthritis ${ }^{1}{ }^{2}$ )
}

\author{
By Jody K. Hargrove ${ }^{1}$, Nancy L. Meryhew ${ }^{1}$ and $O$. A. Runquist ${ }^{2}$ \\ ${ }^{1}$ Department of Medicine, University of Minnesota Medical School, Minneapolis, Minnesota \\ ${ }^{2}$ Department of Chemistry, Hamline University, St. Paul, Minnesota
}

(Received September 26, 1989/April 2, 1990)

Summary: Patients with rheumatoid arthritis have decreased numbers of CR1 per erythrocyte and decreased binding of immune complexes to erythrocytes. Overall erythrocyte immune complex binding activity depends on both the number and the binding kinetics of $\mathrm{CR} 1^{3}$ ). We measured kinetic parameters for the interaction between a complement-containing dsDNA : anti-dsDNA probe and erythrocytes in patients with rheumatoid arthritis and normal controls. The results indicate that:

1) the maximum quantity of immune complexes bound per erythrocyte was significantly decreased in rheumatoid arthritis compared with normal controls $(\mathrm{p} \leq 0.009)$;

2) the steady state binding constant, $\mathrm{K}_{\mathrm{ss}}$, and the association rate constant for binding of immune complexes to erythrocytes, $\mathrm{k}_{\mathrm{a}}$, were significantly increased in rheumatoid arthritis versus normal controls ( $\mathrm{p} \leq 0.0001$ and 0.002 respectively);

3) the dissociation rate constant for the release of bound immune complexes from erythrocytes, $\mathrm{k}_{\mathrm{d}}$, was slightly smaller in rheumatoid arthritis but this difference was not statistically significant; and

4) the energies of activation for the association and dissociation reactions, $E_{a a}$, and $E_{a d}$, did not differ between the two groups.

These data confirm that while the maximum quantity of immune complexes bound per erythrocyte is decreased in rheumatoid arthritis, the association rate constants are larger and dissociation rate constants slightly smaller than those of normal controls. Changes in these kinetic parameters compensate for the decrease in the maximum quantity of immune complexes bound per erythrocyte. A comparison of the product of $\mathrm{K}_{\mathrm{ss}}$ and the maximum quantity of immune complexes bound per erythrocyte revealed no differences in the two groups, indicating that at steady state overall CR1 binding activity is the same. The similar energies of activation imply that the reaction mechanisms for the rate limiting steps of association and dissociation are similar and cannot account for the observed increase in $\mathrm{k}_{\mathrm{a}}$. These data suggest that the increased $\mathrm{k}_{\mathrm{a}}$ results from changes in steric factors, such as the cross sectional area of the CR1 binding site. A model consistent with these observations is presented.

1) This research was supported by the Minnesota Chapter of the Arthritis Foundation.

$\left.{ }^{2}\right)$ Presented in part at the American Rheumatism Association Meeting, Houston, Texas, June 1988.

$\left.{ }^{3}\right)$ Abbreviations used in this paper:

$\mathrm{B}$, amount of DNA:antiDNA:C immune complex per erythrocyte
CR1, erythrocyte receptor for $\mathrm{C} 3 \mathrm{~b}$ component of complement;

$E_{a a}$, energy of activation for association;

$E_{a d}$, energy of activation for dissociation;

$\mathrm{k}_{\mathrm{a}}$, association rate constant;

$\mathrm{k}_{\mathrm{d}}$, dissociation rate constant;

$\mathrm{K}_{\mathrm{ss}}$, steady state constant;

$\mathrm{S}$, amount of immune complexes bound per erythrocyte. 


\section{Introduction}

The erythrocyte receptor for the $\mathrm{C} 3 \mathrm{~b}$ component of complement (CR1) is a single chain glycoprotein found on the surface of peripheral blood cells, which is capable of binding complement-containing immune complexes. CR1 also acts as a cofactor for factor Idependent degradation of bound $\mathrm{C} 3 \mathrm{~b}$ prior to release of immune complexes from the cell surface $(1-4)$. The integral role of these receptors in both immune complex binding and the cleavage of complement products, their abundant numbers in the circulation, and the association of decreased receptor number with active immune complex disease $(5-7)$ suggest an important function for this receptor system in regulating the concentration and character of immune complexes in the circulation. Studies using monoclonal anti-CR1 antibodies have shown that the erythrocytes of patients with rheumatoid arthritis have fewer CR1 receptors than normal controls (8). Taylor et al. have also demonstrated decreased binding of complementcontaining dsDNA : anti-dsDNA immune complexes to erythrocytes in rheumatoid arthritis, compared with erythrocytes from normal controls (9). Whether this decreased binding was due to low levels of receptors, abnormal CR1 binding function, or a combination of these factors was not determined.

The interaction between immune complexes and erythrocyte CR1 involves binding via complement fragments (primarily $\mathrm{C} 3 \mathrm{~b}$ ), complement cleavage and subsequent immune complex release. Due to the consecutive nature of these reactions and the altered size of immune complexes after release $(1,10,11)$, the interaction of immune complexes with erythrocytes cannot be considered a simple receptor-ligand interaction that reaches equilibrium. These consecutive reactions will, however, reach a steady state when the rate of immune complex binding to erythrocytes equals the rate of their release. At steady state maximal binding will occur and there will be no change in the overall concentration of bound immune complexes over time.

The ratio of erythrocyte-bound to unbound immune complexes at steady state is a function of both the rate of association and the rate of dissociation. The rate of association or dissociation is determined by the appropriate rate constant and the concentration of reacting species. Association and dissociation rate constants, $k_{a}$ and $k_{d}$, are independent of reactive species concentrations, but depend upon the energy required for the rate limiting step (energy of activation, $E_{a}$ ) and steric requirements of the respective reactions. Alterations in rate constants secondary to changes in $E_{a}$ or steric conditions and/or concentrations of re- acting species would change the ratio of erythrocytebound to unbound immune complexes in the circulation.

The overall immune complex binding activity of the erythrocyte is regulated by both the binding capacity and the binding function. Erythrocyte binding capacity, defined as the maximum quantity of immune complex which can bind per erythrocyte, is dependent on the number of CR1 per erythrocyte. CR1 binding function is defined by the rate parameters $k_{a}, k_{d}$, and $\mathrm{K}_{\mathrm{ss}}$. The experiments described here were designed to compare immune complex binding capacity per erythrocyte, rate constants of association and dissociation, $\mathrm{k}_{\mathrm{a}}$ and $\mathrm{k}_{\mathrm{d}}$, and the steady state constant, $\mathrm{K}_{\mathrm{ss}}$, for interactions of complement-containing DNA:antiDNA (DNA : anti-DNA : C) immune complexes with erythrocytes from rheumatoid arthritis patients and normal controls. Rate constants were also evaluated at various temperatures, in order to determine energies of activation for the association and dissociation reactions. Using these techniques, we previously demonstrated that erythrocytes from systemic lupus erythematosus patients had decreased immune complex binding capacity, but normal CR1 immune complex binding kinetics (12). In this study we demonstrate that erythrocytes from rheumatoid arthritis patients also have decreased binding capacity, but in addition, have abnormal CR1 immune complex binding kinetics.

\section{Methods and Materials}

\section{Population studied}

Erythrocytes were obtained from 18 patients with rheumatoid arthritis and 15 normal controls. All patients met American Rheumatoid Association (ARA) criteria for the diagnosis of rheumatoid arthritis (13) and were followed in the outpatient clinic at this institution. Nine patients were receiving prednisone therapy with a mean dose of $8.6 \mathrm{mg} /$ day, five patients were on non-steroidal agents alone, and the remaining patients were on combination therapy including non-steroidal agents, prednisone, and/or remittive agents.

\section{Erythrocyte suspensions}

Peripheral blood was collected from normal controls and rheumatoid arthritis patients in standard EDTA tubes. Two $\mathrm{ml}$ of blood were washed twice in gelatin-veronal buffer containing EDTA, four times using gelatin-veronal buffer containing calcium and magnesium (14), and diluted to a $20 \%$ suspension with gelatin-veronal buffer containing calcium and magnesium. Stock solutions of both buffer solutions were prepared, adjusted to a $\mathrm{pH}$ of 7.3 using $1 \mathrm{~mol} / \mathrm{l} \mathrm{HCl}$, and diluted $1: 5$ with deionized water prior to use.

Preparation of DNA : anti-DNA : C immune complexes

$\left[{ }^{3} \mathrm{H}\right]$ DNA $(925 \mathrm{MBq} / \mathrm{l}=25 \mathrm{mCi} / \mathrm{l})$ containing $>96 \%$ dsDNA was obtained from New England Nuclear, Boston, MA. Plasma containing high titer anti-dsDNA antibodies as quantitated by 
ELISA $(15,16)$ was obtained from one systemic lupus erythematosus patient and used for all experiments. Anti-ssDNA antibodies were also present in the plasma, but rheumatoid factor, cryoglobulins, and antibodies directed against acidic nuclear antigens were not detected. Following heat-inactivation at $56{ }^{\circ} \mathrm{C}$ for $30 \mathrm{~min}$, the systemic lupus erythematosus plasma was centrifuged to remove any aggregated materials, aliquoted, and stored at $-20^{\circ} \mathrm{C}$ until used. Lyophilized guinea pig serum was obtained from ICN Immunobiologicals (Lisle, IL), reconstituted and diluted 1:4 in gelatin-veronal buffer containing calcium and magnesium prior to use.

Immune complexes containing $\left[{ }^{3} \mathrm{H}\right] \mathrm{dsDNA}$, anti-dsDNA antibodies, and complement were prepared using a modification of the procedure described by Taylor et al. (9). Aliquots of $\left[{ }^{3} \mathrm{H}\right] \mathrm{dsDNA}$ and plasma containing anti-dsDNA antibodies were diluted in gelatin-veronal buffer containing calcium and magnesium and incubated at $37^{\circ} \mathrm{C}$ for $60 \mathrm{~min}$. Diluted guinea pig sera was added to the $\left[{ }^{3} \mathrm{H}\right] \mathrm{DNA}$ : anti-DNA solution and incubation continued for $30 \mathrm{~min}$ at $37^{\circ} \mathrm{C}$. Preliminary experiments demonstrated that both immune complex formation and activation of complement by these immune complexes reached equilibrium within these incubation times.

\section{Steady state experiments}

The steady state constant, $\mathrm{K}_{\mathrm{ss}}$, and the maximum amount of DNA : anti-DNA : $C$ bound per erythrocyte, were determined by constructing a matrix consisting of varying concentrations of erythrocytes and DNA : anti-DNA : C. Specifically, $\left[{ }^{3} \mathrm{H}\right] \mathrm{DNA}$ $(30 \mu \mathrm{l})$ and anti-DNA $(60 \mu \mathrm{l}$ of plasma) were added to $5.9 \mathrm{ml}$ of gelatin-veronal buffer containing calcium and magnesium, mixed, and incubated for $60 \mathrm{~min}$ at $37^{\circ} \mathrm{C}$. A $4.0 \mathrm{ml}$ aliquot of the DNA : anti-DNA solution was added to $500 \mu$ l of guinea pig complement (diluted 1:4 in gelatin-veronal buffer containing calcium and magnesium) and $1.5 \mathrm{ml}$ of gelatin-veronal buffer containing calcium and magnesium, and incubation continued for $30 \mathrm{~min}$ at $37^{\circ} \mathrm{C}$. This DNA : anti-DNA : C solution was designated "neat" and serial dilutions of $1: 2,1: 4$, and $1: 8$ in gelatin-veronal buffer containing calcium and magnesium were prepared. A $20 \%$ erythrocyte suspension was diluted in gelatin-veronal buffer containing calcium and magnesium to yield $10,5,2.5$, and $1.25 \%$ erythrocyte suspensions.

A four (DNA:anti-DNA:C dilutions) by five (erythrocyte dilutions) matrix was constructed by mixing $100 \mu \mathrm{l}$ of each DNA : anti-DNA : C dilution and $100 \mu \mathrm{l}$ of each erythrocyte suspension, producing a total of 20 solutions with unique immune complex to erythrocyte ratios. Negative control solutions contained $\left[{ }^{3} \mathrm{H}\right] \mathrm{DNA}$ : anti-DNA and erythrocytes only. The matrix and control solutions were incubated at $37^{\circ} \mathrm{C}$ for $30 \mathrm{~min}$, centrifuged, and a $100 \mu \mathrm{l}$ aliquot of each supernatant removed for quantitation of radioactivity. Since bound and unbound radioactivity correlated closely in preliminary experiments, only unbound $\left[{ }^{3} \mathrm{H}\right] \mathrm{DNA}$ : anti-DNA: $\mathrm{C}$ radioactivity (supernatant) was determined. To compare the effect of temperature on both $\mathrm{K}_{\mathrm{ss}}$ and the maximum amount of immune complex bound to erythrocytes, identical matrices were prepared and incubated at $6,15,22$, and $30^{\circ} \mathrm{C}$ until maximal binding was achieved. The length of incubation was extended at cooler temperatures as determined from the plateau of binding noted in preliminary rate experiments at each temperature.

\section{Rate experiments}

The association rate constant, $k_{a}$, for the binding of immune complexes to erythrocytes, the dissociation rate constant, $\mathrm{k}_{\mathrm{d}}$, for the release of erythrocyte-bound immune complexes, and the energies of activation for the association, $E_{a a}$, and dissociation, $E_{a d}$, reactions were determined in the following way. $\left[{ }^{3} \mathrm{H}\right]$ DNA $(35 \mu \mathrm{l})$ and anti-DNA $(70 \mu \mathrm{l}$ of plasma) were added to $6.9 \mathrm{ml}$ of gelatin-veronal buffer containing calcium and magnesium in a polystyrene tube. The solution was mixed and incubated for $60 \mathrm{~min}$ at $37^{\circ} \mathrm{C}$. Guinea pig complement diluted $1: 4$ in gelatin-veronal buffer containing calcium and magnesium $(875 \mu \mathrm{l})$ and $2.6 \mathrm{ml}$ of gelatin-veronal buffer containing calcium and magnesium were then added to the DNA : antiDNA solution, mixed, and incubated for $30 \mathrm{~min}$ at $37^{\circ} \mathrm{C}$. Equivalent amounts of this neat DNA : anti-DNA : C solution and $20 \%$ erythrocyte suspension, both at $37^{\circ} \mathrm{C}$, were rapidly mixed and sixteen timed aliquots $(200 \mu \mathrm{l})$ removed from the reaction mixture over a total of 60-90 min. The aliquots were immediately placed on ice to prevent further reaction, centrifuged at $4{ }^{\circ} \mathrm{C}$, and $100 \mu \mathrm{l}$ aliquots of the supernatants removed for quantitation of radioactivity.

To determine the effect of temperature on $k_{a}$ and $k_{d}$, and to determine $E_{a a}$ and $E_{a d}$, the above procedure was repeated at 6 , 15,22 , and $30^{\circ} \mathrm{C}$ for each normal control and rheumatoid arthritis patient studied. The timing of sample removal was adjusted to account for slower reaction times at cooler temperatures.

\section{Calculations}

The consecutive interaction of immune complexes (IC) and erythrocytes $(\mathrm{RBC})$ is given by equation 1 :

$\mathrm{RBC} C \mathrm{CR} 1+\mathrm{IC} \underset{\mathrm{k}_{\mathrm{d}^{\prime}}}{\stackrel{\mathrm{k}_{\mathrm{a}}}{\rightleftarrows}} \mathrm{RBC} \cdot \mathrm{IC} \stackrel{\mathrm{k}_{d}}{\longrightarrow} \mathrm{RBCCR} 1+\mathrm{IC}^{*}$ (eq. 1)

where IC* represents modified immune complexes which possess little or no affinity for erythrocyte CR1. The constants $k_{a}$ and $\mathrm{k}_{\mathrm{d}}{ }^{\prime}$ govern the rate of association and its reverse reaction respectively, while $\mathrm{k}_{\mathrm{d}}$ governs factor I-mediated immune conplex dissociation. The values of $k_{d}$ determined in these experiments include both $k_{d}$ and $k_{d}{ }^{\prime}$, but the reaction governed by $k_{d}{ }^{\prime}$ has been shown to be much slower than the dissociation reaction governed by $k_{d}(17)$. Since this reaction contributes minimally to the total concentration of unbound immune complexes, the $k_{d}$ determined in this study reflects primarily factor $\mathrm{I}$-mediated $\mathrm{C} 3 \mathrm{~b}$ degradation and immune complex dissociation, and calculations were simplified by not determining a specific value for $\mathrm{k}_{\mathrm{d}}{ }^{\prime}$

Equations (2) and (3) give the relationships between rates of association and dissociation, the respective rate constants $k_{a}$ and $k_{d}$, and concentrations of reactive species. In these equations, $[\mathrm{RBC}]$ and $[\mathrm{IC}]$ represent concentrations of erythrocytes and immune complexes. The maximum amount of DNA : antiDNA: C which can bind per erythrocyte is represented by $S$, while $\mathrm{B}$ represents the amount of DNA : anti-DNA : C actually bound per erythrocyte at a given time.

$$
\begin{aligned}
& \text { rate of association }= \\
& \qquad-\mathrm{d}[\mathrm{IC}] / \mathrm{dt}=\mathrm{ka}(\mathrm{S}[\mathrm{RBC}]-\mathrm{B}[\mathrm{RBC}])([\mathrm{IC}]) \\
& \text { rate of dissociation }= \\
& \quad-\mathrm{d}[\mathrm{RBC} \cdot \mathrm{IC}] / \mathrm{dt}=\mathrm{kdB}[\mathrm{RBC}]
\end{aligned}
$$

At steady state, the rates of association and dissociation are equal and equations (2) and (3) may be combined to give the steady state constant, $\mathrm{K}_{\mathrm{ss}}$ or the ratio of $\mathrm{k}_{\mathrm{a}}$ to $\mathrm{k}_{\mathrm{d}}$ :

$$
\mathrm{K}_{\mathrm{ss}}=\mathrm{k}_{\mathrm{a}} / \mathrm{k}_{\mathrm{d}}=\frac{\mathrm{B}}{(\mathrm{S}-\mathrm{B})([\mathrm{IC}])}
$$

Rearrangement of equation (4) yields:

$$
\frac{1}{\mathrm{~B}}=\frac{1}{\mathrm{~S}}+\frac{1}{\left(\mathrm{~K}_{\mathrm{ss}} \mathrm{S}[\mathrm{IC}]\right)}
$$

Double reciprocal plots of $1 / B$ (i. e., 1 /bound IC per erythrocyte) versus $1 /[$ IC] (i. e., $1 /$ unbound IC) were linear over a broad 
range of immune complex and erythrocyte concentrations. Slopes and intercepts of these plots represented $1 /\left(\mathrm{K}_{\mathrm{ss}}\right)(\mathrm{S})$ and $1 / \mathrm{S}$, respectively.

Rate constants for association were calculated using the initial slopes of solution phase radioactivity (counts/min) versus time plots for the descending portion (binding) of each plot. Since the concentration of immune complexes $[\mathrm{IC}]$ is directly related to the radioactivity of the DNA : anti-DNA : C probe in solution, substitution of the initial slope, the initial radioactivity of the solution $\left(\mathrm{cpm}^{\circ}\right)$, and the concentration of erythrocytes into equation (2), followed by rearrangement, yields equation (6). Values of $\mathrm{k}_{\mathrm{a}} \mathrm{S}$ were calculated from equation (6).

$$
\text { initial slope } /[\mathrm{RBC}] \mathrm{cpm}^{\circ}=\mathrm{k}_{\mathrm{a}} \mathrm{S}
$$

Since $\mathrm{K}_{\mathrm{ss}} \mathrm{S}$ and $\mathrm{k}_{\mathrm{a}} \mathrm{S}$ were determined from double reciprocal plots (equation 5) and rate experiments (equation 6) respectively, $k_{d}$ was calculated from the following relationship:

$$
\mathrm{K}_{\mathrm{ss}} \mathrm{S}=\mathrm{k}_{\mathrm{a}} \mathrm{S} / \mathrm{k}_{\mathrm{d}}
$$

Energies of activation were evaluated from the Arrhenius equation (8):

$$
\ln (\mathrm{k})=\ln (\mathrm{A})-\mathrm{E}_{\mathrm{a}} / \mathrm{RT}
$$

where $A$ is the frequency factor, $R$ is the universal gas constant, $T$ is absolute temperature (Kelvin) and $E_{a}$ is the energy of activation. Plots of $\ln \left(k_{a} S\right)$ and $\ln \left(k_{d}\right)$ versus $1 / T$ were linear with slopes equal to $E_{a a} / R$ and $E_{a d} / R$, respectively.

\section{Statistical analysis of data}

All statistical correlations were obtained using the Pearson product-moment coefficient (RS/1 Statistical Package, BBN Research Systems, Cambridge, MA). Statistical comparisons were made using Student's t-test.

\section{Results}

\section{Binding of immune complexes to erythrocytes}

The interaction of $\left[{ }^{3} \mathrm{H}\right] \mathrm{DNA}$ : anti-DNA : $\mathrm{C}$ complexes with erythrocytes as a function of time is shown in figure 1 . The binding curve is characterized by an initial decline in radioactivity corresponding to net binding of immune complexes to erythrocytes (reaching a maximum in the first ten minutes), a plateau phase (extending up to 50 minutes), and a gradual increase in radioactivity reflecting net immune complex release from erythrocytes mediated by erythrocyte CR1 and factor I. Factor I, present in the donor plasma and lyophilized guinea pig sera (dilutions of $1: 300$ and $1: 25$ respectively) used in preparing the immune complex probe, was constant in all experiments and allowed the binding, complement inactivation, and release reactions to occur consecutively, so that steady state parameters could be evaluated and compared. Additional experiments performed in the presence of incremental doses of purified factor I showed that the initial binding of immune complexes was not altered, while release of immune complexes into the supernatant occurred more rapidly, as noted previously by others $(4,10)$.
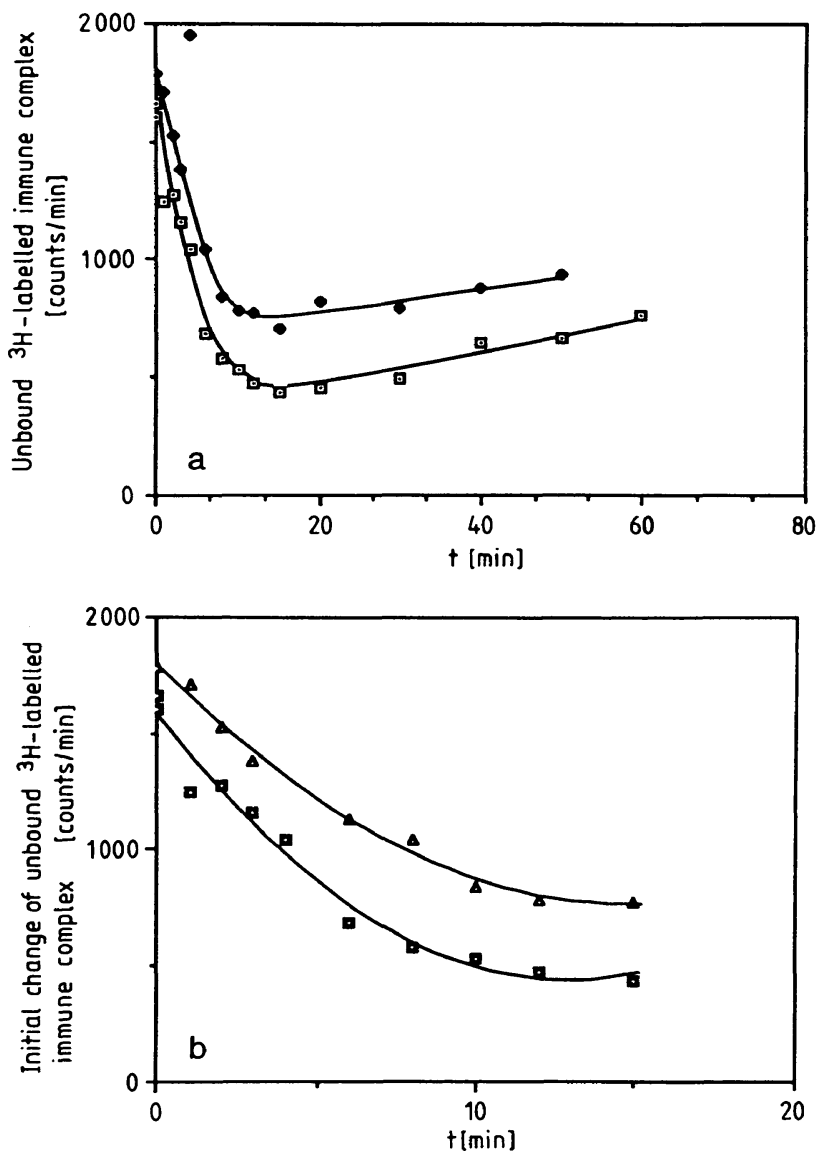

Fig. 1. a) Binding of $\left[{ }^{3} \mathrm{H}\right] \mathrm{DNA}$ : anti-DNA: C complexes to erythrocytes as a function of time in representative normal control $(\diamond)$ and rheumatoid arthritis patient ().

b) Initial change in radioactivity determined from slope of fitted polynomial for points in initial 30 minutes. Steady state measurements made at $30-40$ minutes. Graphs show change in radioactivity of unbound immune complex with time for normal control $(\boldsymbol{\Delta})$ and rheumatoid arthritis patients ( $\square$ ).

The general shape of the association and dissociation curves for the interaction of DNA : anti-DNA : C and erythrocytes at $37^{\circ} \mathrm{C}$ was similar in the 18 rheumatoid arthritis patients and 15 normal controls examined. Curves obtained from experiments performed at decreasing temperatures $\left(30,22,15\right.$, and $\left.6^{\circ} \mathrm{C}\right)$ depicted a progressive prolongation of binding and dissociation at each successively lower temperature.

\section{Steady state binding studies}

The $\mathrm{K}_{\mathrm{ss}}$ and the maximum amount of DNA : antiDNA : $C$ bound per erythrocyte, $S$, were determined by measuring concentrations of erythrocyte-bound and unbound immune complexes at the time of maximal binding. A representative double reciprocal plot illustrating data analysis from these experiments is shown in figure 2. According to equation (5), the slope and intercept of these plots are equivalent to $1 /$ 


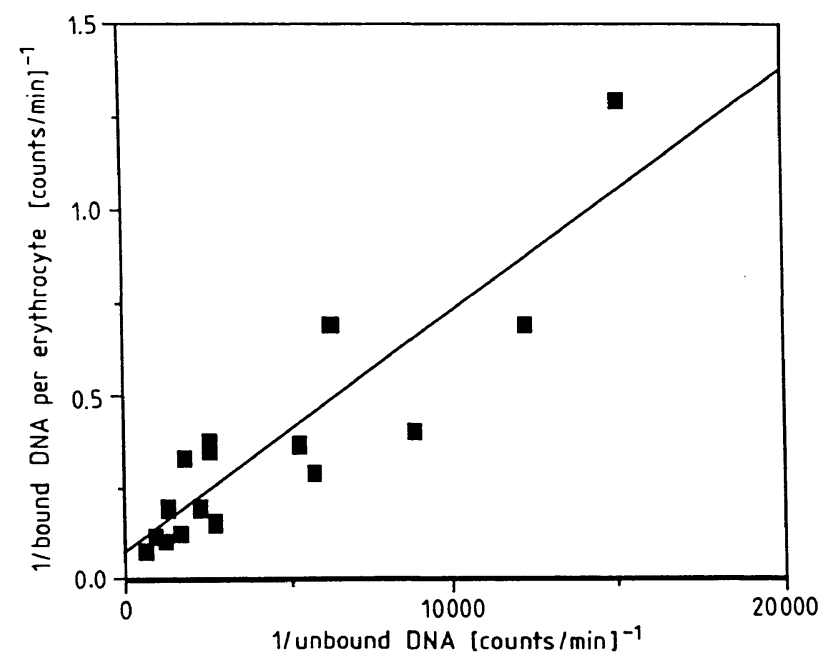

Fig. 2. Double reciprocal plot (equation 5) of steady state concentrations of unbound versus erythrocyte-bound $\left[{ }^{3} \mathrm{H}\right]$ DNA : anti-DNA : $\mathrm{C}$ complexes in a representative rheumatoid arthritis patient.

$\left(\mathrm{K}_{\mathrm{ss}} \mathrm{S}\right)$ and $1 / \mathrm{S}$, respectively. Values of $\mathrm{K}_{\mathrm{ss}}$ and $\mathrm{S}$ determined at five different temperatures are listed in table 1. At all five temperatures the maximum amount of DNA : anti-DNA: C bound per erythrocyte was significantly decreased $(\mathrm{p} \leq 0.009)$, and $\mathrm{K}_{\mathrm{ss}}$ was significantly increased $(p \leq 0.0001)$ in rheumatoid arthritis. To examine the overall effect of a simultaneous increase in $\mathrm{K}_{\mathrm{ss}}$ and a decrease in $\mathrm{S}$, the product $\mathrm{K}_{\mathrm{ss}} \cdot \mathrm{S}$ for the two groups was compared (tab. 1). Despite significantly larger mean $\mathrm{K}_{\mathrm{ss}}$ values in rheumatoid arthritis, the $\mathrm{K}_{\mathrm{ss}} \cdot \mathrm{S}$ product was not statistically different from normal controls. These data suggest that the increased $\mathrm{K}_{\mathrm{ss}}$ compensates for a decreased immune complex binding capacity of erythrocytes in rheumatoid arthritis.

\section{Rate studies}

Rate studies were performed at five temperatures and the rate constants of association, $\mathrm{k}_{\mathrm{a}}$, and dissociation, $k_{d}$, were determined. The results of these studies, given in table 2 , show that the mean rate constant of association, $k_{a}$, is significantly larger in rheumatoid arthritis patients than in normal controls $(\mathrm{p} \leq 0.025)$ at all temperatures. Values of $\mathrm{k}_{\mathrm{a}}$ increased with increasing temperature in both rheumatoid arthritis patients and controls, but the ratio of the mean $k_{a}$ in rheumatoid arthritis patients to the mean $\mathrm{k}_{\mathrm{a}}$ in normal controls remained constant. Values for $k_{d}$ were decreased in rheumatoid arthritis patients compared with controls, but the decrease was not statistically significant. A temperature-dependent increase in $\mathbf{k}_{\mathbf{d}}$ was again noted in both groups, but the ratio of the mean values remained constant.

Tab. 1. Mean values of steady state parameters for association/dissociation of DNA : anti-DNA : C complexes with erythrocytes from rheumatoid arthritis patients and normal controls as a function of temperature

\begin{tabular}{lllll} 
Temperature, ${ }^{\circ} \mathrm{C}$ & & & \\
\hline 6 & 15 & 22 & 30 & 37
\end{tabular}

$\mathrm{S} \times 10^{-15}:$ mg DNA : anti-DNA:C per erythrocyte

Rheumatoid arthritis

$(\mathrm{n}=18)$

Normal controls

$(\mathrm{n}=15)$

Rheumatoid arthritis/normal controls

$\mathrm{p}$

$\mathrm{K}_{\mathrm{ss}} \times 10^{3}$ : litre per mg DNA : anti-DNA :C

Rheumatoid arthritis

( $\mathrm{n}=18)$

Normal controls

( $\mathrm{n}=15)$

$\mathrm{p}$

$\mathrm{K}_{\mathrm{ss}} \mathrm{S} \times 10^{-12}$ : litre per erythrocyte

Rheumatoid arthritis

( $\mathrm{n}=18)$

Normal controls

( $\mathrm{n}=15)$

$\mathrm{p}$

$\begin{array}{rr}21.6 & 24.9 \\ +11.6 & \pm 14.9 \\ 119.5 & 121.2 \\ \pm 139.4 & \pm 68.1\end{array}$

$<0.007$
0.20

29.9
\pm 18.3
116.2
+79.7

$\pm 79.7$

$<0.001$
28.2

$\pm 19.9$

109.6

$\pm 83.0$

0.26

$<0.001$

$<0.001$
28.2
$+\quad 19.9$

$\pm 19.9$

$\pm 106.2$

0.26

$<0.01$ 
Tab. 2. Rate constants of association and dissociation for the interaction of DNA : anti-DNA:C complexes with rheumatoid arthritis and normal control erythrocytes as a function of temperature

\section{Temperature, ${ }^{\circ} \mathrm{C}$}

\begin{tabular}{lllll}
\hline 6 & 15 & 22 & 30 & 37
\end{tabular}

$\mathrm{k}_{\mathrm{a}} \mathrm{S} \times 10^{-15}: 1 \cdot \min ^{-1}$ per erythrocyte

Rheumatoid arthritis

$(\mathrm{n}=18)$

$\begin{array}{rrrrr}20.0 & 33.0 & 50.0 & 69.0 & 93.0 \\ \pm 14.0 & \pm 19.0 & \pm 38.0 & \pm 49.0 & \pm 57.0 \\ 31.0 & 54.0 & 80.0 & 113.0 & 146.0 \\ \pm 18.0 & \pm 27.0 & \pm 30.0 & \pm 40.0 & \pm 67.0\end{array}$

15

37

Normal controls

( $\mathrm{n}=15)$

Rheumatoid arthritis/normal controls

0.64

0.61

0.62

0.61

0.64

$<0.05$

$<0.015$

$<0.025$

$<0.015$

$<0.02$

$\mathrm{k}_{\mathrm{a}}: 1 \cdot \mathrm{mg}^{-1} \cdot \min ^{-1}$

Rheumatoid arthritis

( $\mathrm{n}=18$ )

Normal controls

( $\mathrm{n}=15)$

1.08

$+0.78$

0.38

$\pm 0.26$

Rheumatoid arthritis/normal controls

2.84

$<0.002$

$\mathrm{p}$

$\mathrm{k}_{\mathrm{d}} \times 10^{-3}: \min ^{-1}$

Rheumatoid arthritis

$(\mathrm{n}=18)$

Normal controls

$(\mathrm{n}=15)$

Rheumatoid arthritis/normal controls

$\mathrm{p}$

Rate studies performed at different temperatures also permitted calculation of the energies of activation for both the association and dissociation reactions. The energy of activation reflects the rate of change in rate constants with temperature and provides an estimate of the energy involved in breaking and making mo-

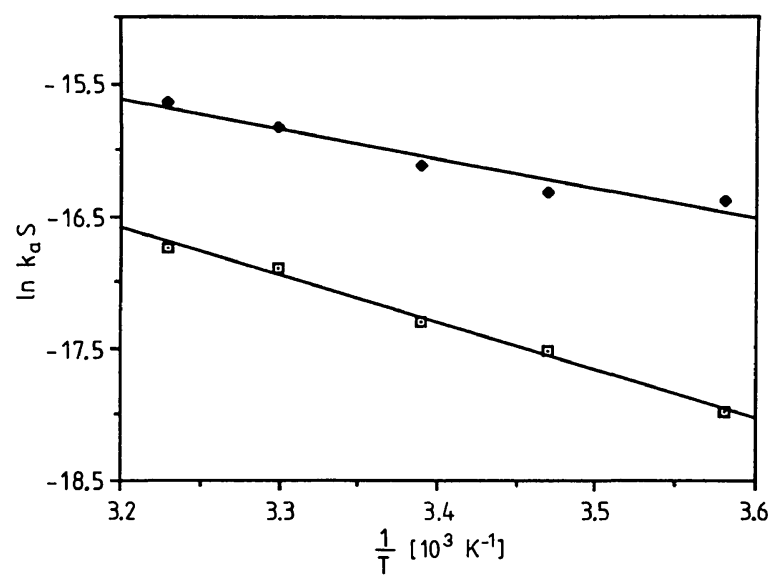

Fig. 3. Arrhenius plots of temperature (Kelvin)-dependent changes in rate constants in representative normal control $(\diamond)$ and rheumatoid arthritis patient $(\square)$. Energies of activation $\left(E_{a a}, E_{a d}\right)$ were determined from slopes of fitted lines. lecular bonds during the rate limiting step of the reaction. Evaluation of this parameter allows a comparison of the molecular mechanisms for the rate determining reactions in the two groups. Individual plots of $\ln \left(k_{\mathrm{a}} \cdot \mathrm{S}\right)$ and $\ln \left(\mathrm{k}_{\mathrm{d}}\right)$ versus $1 / \mathrm{T}$ were linear for both rheumatoid arthritis patients and normal controls (fig. 3). Table 3 lists mean values for $E_{a a}$ and $E_{a d}$ in rheumatoid arthritis patients and controls. The identical energy values observed suggest that the mechanism of the rate determining steps for immune complex binding and release is similar in the two

Tab. 3. Mean energies of activation for association $\left(E_{a a}\right)$ and dissociation $\left(\mathrm{E}_{\mathrm{ad}}\right)$ of DNA : anti-DNA:C interaction with rheumatoid arthritis and normal control erythrocytes

\begin{tabular}{lcc}
\hline & $\begin{array}{l}\mathrm{E}_{\mathrm{aa}} \\
\text { association } \\
(\mathrm{kJ} / \mathrm{mol})\end{array}$ & $\begin{array}{l}\mathrm{E}_{\mathrm{ad}} \\
\text { dissociation } \\
(\mathrm{kJ} / \mathrm{mol})\end{array}$ \\
\hline $\begin{array}{l}\text { Rheumatoid arthritis } \\
(\mathrm{n}=18)\end{array}$ & 37.8 & 41.2 \\
$\begin{array}{l}\text { Normal controls } \\
(\mathrm{n}=15)\end{array}$ & 37.9 & \pm 10.7 \\
\hline
\end{tabular}


groups. The normal $E_{a a}$ values for rheumatoid arthritis patients also suggest that the increase in $\mathrm{k}_{\mathrm{a}}$ was not the result of a different reaction pathway. In addition, the magnitude of the $E_{a a}$ and $E_{a d}$ values (approximately $40 \mathrm{~kJ} / \mathrm{mol}$ ) are comparable to the energy involved in forming or breaking a hydrogen bond $(25-60 \mathrm{~kJ} / \mathrm{mol})$, suggesting that the rate determining steps of immune complex binding and dissociation may involve formation or dissolution of a hydrogen bond.

\section{Discussion}

We have demonstrated that in addition to reduced immune complex binding to erythrocyte $\mathrm{CR} 1 \mathrm{in}$ rheumatoid arthritis there are also abnormalities in the kinetic parameters regulating the interaction of DNA : anti-DNA : C complexes with these receptors. Overall binding characteristics of this receptor system are determined by both binding function, as reflected by $k_{a}, k_{d}$, and $K_{s s}$, and the maximum quantity of immune complex bound per erythrocyte, i.e. S, which is a relative measure of the number of functional binding sites. The rate constant of association, $\mathrm{k}_{\mathrm{a}}$, was significantly larger in rheumatoid arthritis patients than in normal controls at all temperatures, while the rate constant of dissociation, $\mathrm{k}_{\mathrm{d}}$, although decreased in rheumatoid arthritis, was not statistically different from that of the controls. The steady state constant, $\mathrm{K}_{\mathrm{ss}}$ (the ratio $\mathrm{k}_{\mathrm{a}} / \mathrm{k}_{\mathrm{d}}$ ), was significantly larger in rheumatoid arthritis patients. To further investigate the aetiology of the increase in $k_{a}$, we obtained the energy of activation for the association reaction from $\mathrm{Ar}$ rhenius plots of rate data at various temperatures and found no differences in these values for rheumatoid arthritis patients and normal controls. These data suggest that the increase in $\mathrm{k}_{\mathrm{a}}$ observed in rheumatoid arthritis is due to more favourable steric conditions during the interaction of the immune complex probe with erythrocytes.

The maximum amount of immune complexes bound per erythrocyte, $S$, is related to both the number of CR1 binding sites available and the size of the probe used. The composition and size of immune complexes have been shown to affect their interaction with erythrocyte CR1 $(18-20)$. The DNA : anti-DNA : C probe used in these studies was large, containing multiple $\mathrm{C} 3 \mathrm{~b}$ molecules. Binding of such a macromolecule may require interaction with several clustered CR1 molecules which together act as the functional CR1 binding site, while binding of smaller probes such as monoclonal antibodies may involve individual CR1 molecules. Indeed, Paccaud et al. used immunofluorescence and electron microscopy to show that CR1 are clus- tered on the surface of normal erythrocytes and the cluster distribution is unchanged by immune complex binding (21). Their values for the number of CR1 per cell determined with monoclonal antibody $(175-920)$ and the number of clusters per cell as determined by electron microscopy (range 7 to 82 clusters per erythrocyte) correlated strongly, although the absolute values were quite different. Thus, the similar values of $\mathrm{S}$ (as a relative measure of the number of functional CR1 sites per cell) obtained in our experiments and the number of clusters per cell as determined by Paccaud et al. suggest that our DNA : anti-DNA:C probe evaluated $\mathrm{CR} 1$ clusters rather than individual CR1 molecules.

Although the results of these studies reveal abnormalities of both CR1 cluster number and kinetic parameters, the observed increase in $k_{a}$ would be expected to enhance immune complex binding, while decreases in cluster number would contribute to decreased immune complex binding. Since the rate of immune complex binding is a function of $k_{a} \cdot S$ (equation 2), the overall effect of these two opposing factors can be estimated by comparing $\mathrm{k}_{\mathrm{a}} \cdot \mathrm{S}$ in rheumatoid arthritis and normal controls. The mean $\mathrm{k}_{\mathrm{a}} \cdot \mathrm{S}$ is significantly lower in rheumatoid arthritis than in controls $(\mathrm{p}<0.02)$, indicating that the increase in $\mathrm{k}_{\mathrm{a}}$ only partially compensates for lower receptor binding capacity, S.

The dissociation rate constant in rheumatoid arthritis was lower than the control values, although the difference was not statistically significant. Nonetheless, even a small decrease in $k_{d}$ contributes to the increased value of $\mathrm{K}_{\mathrm{ss}}$ in rheumatoid arthritis, since $\mathrm{K}_{\mathrm{ss}}$ is defined by the ratio of $k_{a} / k_{d}$. An increase in this ratio leads to a larger ratio of erythrocyte-bound to free immune complex. To assess the overall effect of the changes in $\mathrm{k}_{\mathrm{a}}, \mathrm{k}_{\mathrm{d}}$, and $\mathrm{S}$, we compared the ratio of the rate of association to the rate of dissociation in rheumatoid arthritis and normal controls. This ratio, expressed by the product of $\mathrm{K}_{\mathrm{ss}} \cdot \mathrm{S}$, was not different in the two groups. The overall binding activity of erythrocyte CR1 at steady state, therefore, as measured by both binding capacity and binding function, is normal in rheumatoid arthritis. This normal binding activity is due to an increase in $\mathrm{k}_{\mathrm{a}}$ and decrease in $\mathrm{k}_{\mathrm{d}}$ which compensate for the decreased binding capacity, S. Interestingly, this contrasts with results of similar studies performed in our laboratory in systemic lupus erythematosus patients, who also had decreased binding capacity, $\mathrm{S}$, but normal $\mathrm{K}_{\mathrm{ss}}, \mathrm{k}_{\mathrm{a}}$, and $\mathrm{k}_{\mathrm{d}}$ values. The compensatory changes in $\mathrm{k}_{\mathrm{a}}$ and $\mathrm{k}_{\mathrm{d}}$ seen in rheumatoid arthritis may play a role in modulating immune complex-mediated disease manifestations. The relative failure of $k_{a}$ and $k_{d}$ to change in a similar fashion 
may contribute to the abnormal handling of immune complexes in systemic lupus erythematosus.

To further examine factors contributing to the increased $\mathbf{k}_{\mathrm{a}}$ observed in rheumatoid arthritis, rate experiments were performed at different temperatures. The Arrhenius equation (equation 8 ) defines the rate constant for a reaction in terms of an energy factor (energy of activation, $E_{a}$ ) and a steric factor (the frequency factor, A). The increase in $k_{a}$ seen in rheumatoid arthritis must result from either an increase in the frequency factor or a decrease in the energy of activation. The frequency factor is related to steric conditions including the cross sectional area of reacting molecules and the reduced mass of colliding molecules. Since the mean value of $E_{a a}$ was normal in rheumatoid arthritis this parameter does not account for the increase in $k_{a}$. Consequently, the larger $k_{a}$ value must result from an increase in the frequency factor, A. Finally, the changes in $k_{a}$ and $A$ in rheumatoid arthritis may be accounted for by an increase in the cross-sectional area of the functional CR1 binding site.

\section{References}

1. Medof, M. E., Iida, K., Mold, C. \& Nussenzweig, V. (1982) Unique role of the complement receptor CR1 in the degradation of $\mathrm{C} 3 \mathrm{~b}$ associated with immune complexes. J. Exp. Med. 156, 1739-1754.

2. Medof, M. E., Prince, G. M. \& Mold, C. (1982) Release of soluble immune complexes from immune adherence receptors on human erythrocytes is mediated by $\mathrm{C} 3 \mathrm{~b}$ inactivator independently of $\mathrm{B} 1 \mathrm{H}$ and is accompanied by generation of C3c. Proc. Natl. Acad. Sci. USA 79, 5047-5051.

3. Medicus, R. G., Melamed, G. T. \& Arnaout, M. A. (1983) Role of human factor I and C3b receptor in the cleavage of surface bound C3bi molecules. Eur. J. Immunol. 13, $465-470$.

4. Jepsen, H. H., Svehag, S. E., Jensenius, J. C. \& Sim, R. B. (1986) Release of immune complexes bound to erythrocyte complement receptor (CR1), with particular reference to the role of Factor I. Scand. J. Immunol. 24, 205-213.

5. Inada, Y., Kamiyama, M., Kanemitsu, T., Hyman, C. L. \& Clark, W. S. (1982) Studies on immune adherence (C3b) receptor activity of human erythrocytes: Relationship between receptor activity and presence of immune complexes in serum. Clin. Exp. Immunol. 50, 189-197.

6. Wilson, J. G., Jack, R. M., Wong, W. W., Schur, P. H. \& Fearon, D. T. (1985) Autoantibody to the C3b/C4b receptor and absence of this receptor from erythrocytes of a patient with systemic lupus erythematosus. J. Clin. Invest. 76, $182-190$.

7. Ross, G. D., Yount, W. J., Walport, M. J., Winfield, J. D., Parker, C. J., Fuller, C. R., Taylor, R. P., Myones, B. L. \& Lachman, P. J. (1985) Disease-associated loss of erythrocyte complement receptors (CR1, C3b receptors) in patients with systemic lupus erythematosus and other diseases involving autoantibodies and/or complement activation. J. Immunol. $135,2005-2014$.

8. Iida, K., Mornaghi, R. \& Nussenzweig, V. (1982) Complement receptor (CR1) deficiency in erythrocytes from patients with systemic lupus erythematosus. J. Exp. Med. 155, $1427-1438$.
In the context of the work of Paccaud et al. showing that immune complexes bind to a cluster of CR1 molecules on the erythrocyte surface, a model consistent with our data suggests that erythrocytes from rheumatoid arthritis patients have fewer binding clusters per cell than normal controls, but more CR1 molecules in each binding cluster. Individual CR1 molecules within these binding clusters are structurally identical. The model accounts for the decreased binding of large probes, such as DNA : anti-DNA : C, by a decrease in the number of binding clusters. Similarly, the larger $k_{a}$ can be accounted for by an increased number of CR1 molecules per cluster. More CR1 molecules per binding cluster would increase the cross-sectional area of the binding site thereby increasing the value of the frequency factor and leading to an increase in $k_{a}$ as observed in our experiments. Finally, a normal $\mathrm{E}_{\mathrm{a}}$ would be expected if the individual CR1 molecules in rheumatoid arthritis and normal controls were structurally identical, so that the rate limiting step of binding would be unaffected.

9. Taylor, R. P., Horgan, C., Buschbacher, R., Brunner, C. M., Hess, C. E., O’Brien, W. M. \& Wanebo, H. J. (1983) Decreased complement mediated binding of antibody $/ 3 \mathrm{H}-$ dsDNA immune complexes to the red blood cells of patients with systemic lupus erythematosus, rheumatoid arthritis, and hematologic malignancies. Arthritis Rheum. 26, 736743.

10. Medof, M. E., Prince, G. M. \& Oger, J. J. F. (1982) Kinetics of interaction of immune complexes with complement receptors on human blood cells: Modification of complexes during interaction with red cells. Clin. Exp. Immunol. 48, $715-725$.

11. Medof, M. E. \& Prince, G. M. (1983) Immune complex alterations occur on the human red blood cell membrane. Immunol. 50, 11-18.

12. Meryhew, N. L., Westling, P. R., Eerdmans, M. E., Janecek, E. J. \& Runquist, O. A. (1989) A kinetic study of erythrocyte DNA/anti-DNA immune complex association and dissociation reactions in systemic lupus erythematosus. Biochim. Biophys. Acta 991, 470-476.

13. Arnett, F. C., Edworthy, S. M., Bloch, D. A., McShane, D. J., Fries, J. F., Cooper, N. S., Healey, L. A., Kaplan, S. R., Liang, M. H., Luthra, H. S., Medsger, T. A., Mitchell, D. M., Neustadt, D. H., Pinals, R. S., Schaller, J. G., Sharp, J. T., Wilder, R. L. \& Hunder, G. G. (1988) Diagnostic criteria for rheumatoid arthritis. Arthritis Rheum. $31,315-324$.

14. Nelson, R. A., Jensen, J., Gigli, I. \& Tamura, N. (1966) Methods for the separation, purification, and measure of nine components of hemolytic complement in guinea-pig serum. Immunochem. 3, 111-135.

15. Rubin, R. L., Joslin, F. G. \& Tan, E. M. (1983) An improved ELISA for anti-native DNA by elimination of interference by anti-histone antibodies. J. Immunol. Methods. 63, 359-366.

16. Eaton, R. B., Schneider, G. \& Schur, P. H. (1982) Enzyme immunoassay for antibody to native DNA. Specificity and quality of antibodies. Arthritis Rheum. 26, 52-62. 
17. Horgan, C., Burge, J., Crawford, L. \& Taylor, R. P. (1984) The kinetics of $[3 \mathrm{H}]$-dsDNA/anti-DNA immune complex formation, binding by red blood cells and release into serum: Effect of DNA molecular weight and conditions of antibody excess. J. Immunol. 133, 2079-2084.

18. Taylor, R. P., Waller, S. J., Haden, C. \& Addis, D. J. (1980) Stability of DNA/anti-DNA complexes: Kinetic control of immune complex size. J. Immunol. 124, $2571-2577$.

19. Lennek, R. A., Baldwin, A. S., Waller, S. J., Morley, K. W. \& Taylor, R. P. (1981) Studies of the physical biochemistry and complement-fixing properties of DNA/anti-DNA immune complexes. J. Immunol. 127, 602-608.
20. Waller, S. J., Taylor, R. P., Wright, E. L., Morley, K. W. \& Johns, M. (1981) DNA/anti-DNA complexes: Correlation of size and complement fixation. Arthritis Rheum. 24, $651-657$.

21. Paccaud, J. P., Carpentier, J. L. \& Schifferli, J. A. (1988) J. Immunol. 141, 3889-3894.

\author{
Nancy Meryhew \\ Box 108 UMHC \\ University of Minnesota \\ Minneapolis \\ Minnesota, 55455, USA
}


